\section{Hjem - når man blir gammel}

Hauge S, Jacobsen FF, red.

Hjem

Eldre og hjemlighet. 177 s. Oslo: Cappelen

Damm, 2008. Pris NOK 289

ISBN 978-82-02-283742

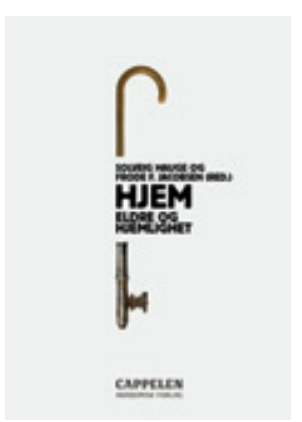

Hjemmet er mer enn et sted å bo. Det er uløselig knyttet til grunnleggende og avgjørende verdier i menneskelivet, verdier som trygghet, identitet, autonomi og hjemmefølelse. I en eldgammel og ofte

sitert engelsk setning sies det slik: «For a man's house is his castle» (sir Edward Coke 1552-1634). Forfatterne beskriver og drøfter hjemmefølelsen og det den betyr gjennom livet, særlig i den siste delen av livet med sykepleie $i$ eget hjem eller i sykehjem.

Boken har tre deler: Eldre og hjemlighet i Norge, hjem og tilhørighet for den syke eldre og hjemlighet i sykehjem. Hver del har tre kapitler. Det er, naturlig nok, mye overlapping mellom kapitlene, for den store utfordringen er å bevare hjemligheten når hjemmet invaderes av kommunens hjelpere og - enda vanskeligere - å skape hjem og hjemmefølelse i sykehjemmet. Sju av forfatterne er sykepleiere med omfattende tilleggsutdanning, en er psykolog og en er antropolog. Målgruppen er studenter innenfor sykepleie, sosial- og helsefagene og de tverrfaglige videreutdanningene innen eldreomsorg, psykisk helsearbeid og rehabilitering.

Forfatterne kjenner temaet ut og inn, både i teori og praksis, og de beskriver sine gode og vonde erfaringer. Hjemlighet skapes og bevares gjennom fysisk tilrettelegging og gjennom utdanning, kultur og ledelse. Den største utfordringen er å skape hjemlighet og hjemmefølelse i sykehjem. Det er og blir vanskelige konflikter mellom profesjonell pleie, effektivitet og økonomi på den ene siden og varme, nærhet og tilhørighet på den annen side. Forfatterne beskriver og drøfter denne konflikten ut fra deres ståsted og erfaringer. Løsningene omfatter fysisk tilrettelegging, kultur, trivsel, utdanning og ledelse. Alle forfat- terne unngår ett stort problem, og det er mangelen på kontinuitet, spesielt $\mathrm{i}$ hjemmesykepleien.

Forfatterne har lang undervisningserfaring fra høyskolene. De skriver godt, men jeg tror at en kortere og enklere bok hadde truffet målgruppen bedre. Målet er ikke bare å informere de unge, men å få dem til å tenke: Sånn vil jeg bli!

Både fastlegene og sykehjemslegene møter de gamle i deres siste hjem i livet, og legene kan ha en avgjørende innflytelse på hvordan denne delen av livet deres blir. Derfor må de tenke grundig over den utfordringen som ligger i begrepet «hjem». De behøver ikke lese fra perm til perm, men må kjenne resonnementene - og på den måten er denne boken nyttig.

Peter F. Hjort

Blommenholm

\section{Sjelden bok om viktig tema}

Eknes J, Bakken TL, Løkke JA et al. Utredning og diagnostisering Utviklingshemning, psykiske lidelser og atferdsvansker. 306 s, tab, ill. Oslo: Universitetsforlaget 2008. Pris NOK 399 ISBN 978-82-15-01301-5

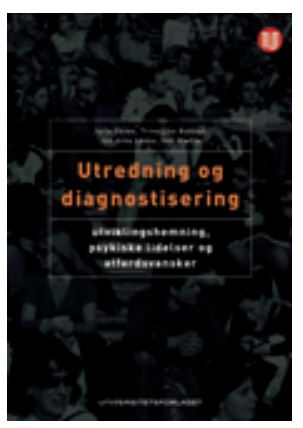

Universitets- og høyskoleutdannet helsepersonell, pedagoger inkludert, samt studenter er målgruppen. Boken angis, med rette, å være av interesse for spesialisthelsetjenesten - særlig psykisk helsevern og habiliteringstjenestene.

Det er kapitler fra i alt 14 bidragsytere, alle med erfaring fra praksisfeltet. Første hoveddel omhandler utredning (som vidt begrep) av utviklingshemning og autisme, der oppmerksomheten rettes mot utredning av selve funksjonshemningene både hos barn og voksne.

Andre hoveddel omhandler kartlegging og utredning av psykiske lidelser og atferdsforstyrrelser. Størst omfang er gitt ulike kartleggingsredskap myntet på først- nevnte. Et kapittel beskriver viktig somatisk differensialdiagnostikk.

Den tredje hoveddelen gjelder diagnostisering av atferdsforstyrrelser, psykiske og nevropsykiatriske lidelser. I all hovedsak disponeres innholdet ut fra eksisterende kriterieoppsett i ICD-10 og DSM-IV og i de kriteriesettene som er spesialutviklet for bedre å kunne fange opp aktuell fenomenologi hos personer med psykisk utviklingshemning.

$\AA$ være oppslagsverk er ett av bokens formål. Det understrekes at kapitlene ikke bør betraktes uavhengig av hverandre.

Psykiatri og atferdsproblematikk hos mennesker med psykisk utviklingshemning eller autisme er sammensatt. Mange berøres. Akademisk norsk psykiatri har langt på vei ikke viet feltet oppmerksomhet, så fagbøker fra praksisfeltet er sjeldne og velkomne.

At faginnsatsen skjer med et samlet bio-, psyko- og sosialt perspektiv for øye, er allment understreket. I tråd med dette omtaler redaksjonen $\mathrm{i}$ introduksjonen at for man stiller diagnoser, må en bredspektret og grundig vurdering finne sted. Mulighet til og hensikt med å nå frem til presise diagnoser er et debattema hva gjelder deler av det diagnostiske mangfoldet - også det er synliggjort i boken.

De enkelte forfatterne synes i ulik grad å presentere slike typer avveininger. Lest med omhu og som en helhet taper ikke boken nødvendigvis på slike forskjeller. Kompleksiteten i og bredden av fagområdet blir snarere fremhevet. Som studentlitteratur blir den imidlertid mer krevende.

For leger er det av verdi å få et innblikk i utredninger som gjelder funksjonsnedsettelsen, også det som andre profesjoner ivaretar. Nyttig er orienteringer om og anvisninger til kartleggingsredskapene for personer med psykisk utviklingshemning.

Presis diagnostisering vil primært være oppgave for spesialisthelsetjenesten. Detaljrikdommen i boken kan for andre kanskje virke overveldende.

Psykiatri og atferdstematikken favner betydelig videre enn hovedfokuset utredning, kartlegging og diagnostisering. Langt flere enn dem en slik bok primært er planlagt for, har informasjons- og kunnskapsbehov. Den kan forhåpentligvis anspore til oppfølgere og til annen kunnskapsspredning.

Tyngre flerfaglig korrektur kunne trolig fjernet noen uklarheter og noen få tilsynela- 